\title{
MINOCYCLINE PROVIDES PROTECTION AGAINST $\beta$-AMYLOID(25-35)- INDUCED ALTERATIONS OF THE SOMATOSTATIN SIGNALING PATHWAY IN THE RAT TEMPORAL CORTEX
}

\author{
E. BURGOS-RAMOS, ${ }^{\text {a,b }}$ L. PUEBLA-JIMÉNEZ ${ }^{c}$ AND \\ E. ARILLA-FERREIRO ${ }^{\mathrm{c} *}$ \\ ${ }^{a}$ Departamento de Endocrinología, Hospital Infantil Universitario Niño \\ Jesús, Madrid, Spain \\ ${ }^{b}$ CIBER Fisiopatología de la Obesidad y Nutrición (CIBEROBN), In- \\ stituto de Salud Carlos III, Avda. Menéndez Pelayo 65, E-28009 \\ Madrid, Spain \\ 'Grupo de Neurobioquímica, Departamento de Bioquímica y Biología \\ Molecular, Facultad de Medicina, Universidad de Alcalá, Ctra. Madrid- \\ Barcelona km 33.6, Alcalá de Henares E-28871, Madrid, Spain
}

\begin{abstract}
Minocycline is a semi-synthetic second-generation tetracycline known to improve cognition in amyloid precursor protein transgenic mice. Whether it can protect the somatostatin (SRIF) receptor-effector system, also involved in learning and memory, from alterations induced by chronic i.c.v. infusion of $\beta$-amyloid peptide (A $\beta)(25-35)$ is presently unknown. Hence, in the present study, we tested the effects of minocycline on the SRIF signaling pathway in the rat temporal cortex. To this end, male Wistar rats were injected with minocycline $(45 \mathrm{mg} / \mathrm{kg}$ body weight) i.p. twice on the first day of treatment. On the following day and during 14 days, $A \beta(25-35)$ was administered i.c.v. via an osmotic minipump connected to a cannula implanted in the left lateral ventricle (300 pmol/day). Minocycline $(22.5 \mathrm{mg} / \mathrm{kg}$, i.p.) was injected once again the last 2 days of the $A \beta(25-35)$ infusion. The animals were killed by decapitation $24 \mathrm{~h}$ after the last drug injection. Our results show that minocycline prevents the decrease in SRIF receptor density and somatostatin receptor (sst) 2 expression and the attenuated capacity of SRIF to inhibit adenylyl cyclase (AC) activity, alterations present in the temporal cortex of $A \beta(25-35)$-treated rats. Furthermore, minocycline blocks the $A \beta(25-35)$-induced decrease in phosphorylated cyclic AMP (cAMP) response element binding protein ( $p$-CREB) content and G-protein-coupled receptor kinase 2 (GRK) protein expression in this brain area. Altogether, the present data demonstrate that minocycline in vivo provides protection against $A \beta$-induced impairment of the SRIF signal transduction pathway in the rat temporal cortex and suggest that it may have a potential as a therapeutic agent in human Alzheimer's disease, although further studies are warranted. ( 2008 IBRO. Published by Elsevier Ltd. All rights reserved.
\end{abstract}

\footnotetext{
${ }^{*}$ Corresponding author. Tel: +34-91-885-4509; fax: +34-91-885-4585. E-mail address: burgosemma@hotmail.com (E. Arilla Ferreiro).

Abbreviations: $A C$, adenylyl cyclase; $A D$, Alzheimer's disease; $A \beta$, $\beta$-amyloid peptide; BSA, bovine serum albumin; CAMP, cyclic AMP; CRE, cyclic AMP response element; CREB, cyclic AMP response element binding protein; FK, forskolin; GPCR, G-protein-coupled receptor; GRK, G-protein-coupled receptor kinase; IBMX, 3-isobutyl-1methylxantine; MMLV-RT, Moloney murine leukemia virus reverse transcriptase; p-CREB, phosphorylated cyclic AMP response element binding protein; PKC, protein kinase C; PMSF, phenylmethylsulfonyl fluoride; RT, reverse transcription; SRIF, somatostatin; sst, somatostatin receptor.
}

Key words: brain, Alzheimer's disease, amyloid-beta, CREB, GRK, somatostatin receptors.

The peptide somatostatin (SRIF) is widely distributed throughout the brain and periphery, where it exerts a variety of hormonal and neuronal actions (Patel, 1999). In the temporal cortex, an area involved in cognitive functions, SRIF plays an important role as a neurotransmitter and has been implicated in learning and memory processes (Dournaud et al., 1996). Its biological actions are mediated by receptors belonging to the G-protein-coupled receptor (GPCR) family. Five SRIF receptor subtypes, termed somatostatin receptor (sst) 1-sst5, have been identified in mammals, with two splice variants of sst2 in mouse and rat, sst2A and sst2B (Hoyer et al., 1995). Sst1-sst4 are highly expressed in the cortex whereas sst5 receptor immunoreactivity is only sparsely present in neuronal perikarya and proximal dendrites limited to the rostral part of the brain (Stroh et al., 2000). Ssts elicit their cellular responses via G-protein-linked-modulation of multiple second-messenger systems including adenylyl cyclase (AC), $\mathrm{Ca}^{2+}$ and $\mathrm{K}^{+}$ion channels, $\mathrm{Na}^{+} / \mathrm{H}^{+}$antiporter, guanylate cyclase, phospholipase $\mathrm{C}$, phospholipase $\mathrm{A}_{2}$, MAP kinase, and serine, threonine and phosphotyrosyl protein phosphatase (Patel, 1999).

Over the years, considerable evidence has accumulated pointing toward a close relationship between SRIF, Alzheimer's disease (AD) and amyloid-beta peptide $(A \beta)$. Among the numerous neuropeptides produced in intrinsic cortical and hippocampal neurons, SRIF has been found to be the most consistently reduced in the brain and cerebrospinal fluid of AD patients (Davies et al., 1980; Beal et al., 1986; Nemeroff et al., 1992; Bissette et al., 1998; BurgosRamos et al., 2008). SRIF receptors are also markedly depleted in the AD brain (Beal et al., 1985), there being subtype-selective alterations in cortical areas (Kumar, 2005). AD is characterized clinically by progressive dementia and, histopathologically, by the presence of extracellular deposits of amyloid fibrils in the core of senile plaques, intracellular neurofibrillar tangles and neuronal cell loss (Braak and Braak, 1991; Selkoe, 2001). One of the principal components of senile plaques is $A \beta$, which is considered to be involved in the pathogenesis of $A D$ (Hsiao et al., 1996; Selkoe, 2001). Our group has recently shown that chronic $A \beta(25-35)$ infusion, an animal model of $A D$, decreases sst density and expression in the rat frontoparietal cortex (Hervás-Aguilar et al., 2005) and temporal 
cortex (Aguado-Llera et al., 2005), an effect accompanied by decreased receptor functionality.

Minocycline is a semisynthetic second-generation tetracycline which is used clinically as an antimicrobial agent. In addition to its efficacy in the treatment of multidrugresistant infections, this antibiotic has a good clinical safety record and is a highly lipophilic molecule which easily penetrates the blood-brain barrier (Aronson, 1980). In recent years, it has been shown to exhibit powerful antiinflammatory properties that are completely distinct from its antimicrobial action. As a result, minocycline has been shown to ameliorate disease severity in several animal models of neurological diseases, including stroke, amyotrophic lateral sclerosis, Huntington's disease and Parkinson's disease (Bantubungi et al., 2005). A recent report demonstrated that minocycline inhibits $A \beta$-induced neuronal death and glial activation in the rat hippocampus (Ryu et al., 2004). Minocycline has also been reported to affect $\mathrm{A} \beta$ deposition and behavior in amyloid precursor protein transgenic mice and to improve cognition in young mice (Seabrook et al., 2006). In addition, Hunter et al. (2004), using an experimental model of $A D$ in mice, have documented that minocycline reduces the magnitude of cholinergic fiber loss in the hippocampus and attenuates cognitive impairment. To date, however, it is unknown whether minocycline can protect the SRIF receptor-effector system from alterations present in the AD brain and after chronic A $\beta$ infusion (Aguado-Llera et al., 2005; Hervás-Aguilar et al., 2005). To address this issue, we examined the effects of minocycline on: ${ }^{125}$ I-Tyr ${ }^{11}$-SRIF binding to SRIF receptors, sst1-sst 4 protein expression, sst mRNA levels, phosphorylated and total cyclic AMP (CAMP) response element binding protein (CREB) content, basal and stimulated AC activity, SRIF-induced inhibition of AC activity and Gi $\alpha 1-$ Gi $\alpha 3$ protein levels in the temporal cortex of control and $\mathrm{A} \beta(25-35)$-treated rats. In addition, since $\mathrm{G}$ protein-coupled receptor kinases (GRKs) play a key role in the regulation of GPCR function (Gainetdinov et al., 2004) and GRK alterations appear to be closely associated with very early accumulation of soluble $A \beta$ peptide in the brain (Suo et al., 2004), the protein content of the isoform GRK2 in the temporal cortex of control, minocycline-, $\mathrm{A} \beta(25-35)$ - and minocycline plus $A \beta(25-35)$-treated rats was also assessed.

\section{EXPERIMENTAL PROCEDURES}

\section{Reagents}

Synthetic Tyr ${ }^{11}$-SRIF and SRIF-14 were purchased from Universal Biologicals Ltd. (Cambridge, UK); carrier-free $\mathrm{Na}^{125}$ I (IMS 100 $\mathrm{mCi} / \mathrm{mL}$ ) was purchased from the Radiochemical Center (Perkin Elmer, Boston, MA, USA); bacitracin, bovine serum albumin (BSA), forskolin (FK), $A \beta(25-35)$, minocycline, phenylmethylsulfonyl fluoride (PMSF), guanosine triphosphate, 3-isobutyl-1-methylxantine (IBMX) and the specific antibody against total-CREB were purchased from Sigma (Madrid, Spain). TriReagent for RNA isolation was from Molecular Research Center (Cincinnati, OH, USA). DNase I RNase-free was purchased from Roche Applied Science (Indianapolis, IN, USA). Moloney murine leukemia virus reverse transcriptase (MMLV-RT) and other reagents for the reverse transcription reaction (RT) were obtained from Invitrogen
Ltd. (Barcelona, Spain). Specific monoclonal antibodies to the $\alpha \mathrm{i} 1$ (MAB 3075) or $\alpha \mathrm{i} 2$ (MAB 3077) G protein subunits were obtained from Chemicon International (Temecula, CA, USA). The specific antisera against the $\alpha \mathrm{i} 3 \mathrm{G}$ protein subunit (sc-262), the SRIF receptor subtypes sst1 (sc-11604), sst2 (sc-11606), sst3 (sc11614) and sst4 (sc-11619), as well as the antibody to GRK2 (sc-13143) were obtained from Santa Cruz Biotechnology Inc. (Santa Cruz, CA, USA). The specific antibody to phospho-CREB was purchased from Cell Signaling (Boston, MA, USA). Nitrocellulose membranes and the chemiluminescence Western blotting detection system were purchased from Amersham (Buckinghamshire, UK).

\section{Experimental animals}

The rats were treated according to the European Community laws for animal care and the experiment was approved by the Animal Care Committee of Alcalá University. All efforts were made to minimize animal suffering and to use only the number of animals deemed necessary to produce reliable scientific data. Forty male Wistar rats weighing 200-250 g were used in this study. All animals received food and tap water ad libitum. Room temperature was kept at $22^{\circ} \mathrm{C}$ and a 12-h light/dark cycle was maintained. The $A \beta(25-35)$ peptide was dissolved in $1 \%$ acetic acid according to the manufacturer's instructions and was incubated at $37^{\circ} \mathrm{C}$ the day before its administration. On the day of surgery, a cannula attached to an osmotic minipump (Alzet) was implanted in the rat left lateral cerebral ventricle, as previously described (Nitta et al., $1994)$ and $A \beta(25-35)$ was continuously infused at a dose of 300 pmol/day for 14 days (Nitta et al., 1994). Another group of male Wistar rats was injected with minocycline $(45 \mathrm{mg} / \mathrm{kg}$ body weight) i.p. twice on the first day of treatment (Yrjänheikki et al., 1999). On the following day and during 14 days, $A \beta(25-35)$ was administered i.c.v. via an osmotic minipump connected to a cannula implanted in the left lateral ventricle (300 pmol/day). Minocycline $(22.5 \mathrm{mg} /$ $\mathrm{kg}$, i.p.) was injected once again the last 2 days of the $A \beta(25-35)$ infusion. A third group of rats received a similar treatment with minocycline in the absence of $A \beta(25-35)$ infusion. Control animals received equivalent volumes of vehicle. All animals were decapitated 14 days after the first injection. The brains were quickly removed from the skull and the temporal cortex was immediately dissected on ice.

\section{Membrane preparation}

The temporal cortex was homogenized in $10 \mathrm{mM}$ Hepes- $\mathrm{KOH}$ buffer, pH 7.6 (10\% wt/vol) with a Brinkmann polytron homogenizer (setting $5,15 \mathrm{~s}$ ). The homogenate was spun at $600 \times \mathrm{g}$ for 5 min at $4{ }^{\circ} \mathrm{C}$, and the supernatant was centrifuged at $48,000 \times g$ for $30 \mathrm{~min}$ at $4{ }^{\circ} \mathrm{C}$. The resulting pellet was suspended in $10 \mathrm{mM}$ Hepes- $\mathrm{KOH}, \mathrm{pH} 7.6(10 \% \mathrm{w} / \mathrm{v})$ and then centrifuged as before. The resultant pellet was resuspended in $50 \mathrm{mM}$ Tris-HCl buffer, $\mathrm{pH}$ 7.5. Samples were immediately aliquoted and stored at $-80{ }^{\circ} \mathrm{C}$ until the day of assay.

\section{Preparation of cell lysate}

A small sample of the temporal cortex from the different experimental animals was isolated and suspended in $500 \mu \mathrm{l}$ of lysis buffer $(20 \mathrm{mM}$ Hepes, $150 \mathrm{mM} \mathrm{NaCl}, 1 \mathrm{mM}$ EDTA, 1\% Triton $\mathrm{X}-100,5 \%$ glycerol, $10 \mathrm{mM}$ pyrophosphate, $1 \mathrm{mM} \mathrm{NaVO}_{3}, 1 \mathrm{mM}$ PMSF, $5 \mu \mathrm{g} / \mathrm{mL}$ aprotinin, $5 \mu \mathrm{g} / \mathrm{mL} \mathrm{STI}$ and leupeptin, $\mathrm{pH}$ 7.5). The samples were sonicated for $5 \mathrm{~s}$, allowed to incubate on ice for $30 \mathrm{~min}$ with agitation, and then cleared by centrifugation in a tabletop centrifuge at $15,000 \times g$ at $4^{\circ} \mathrm{C}$ for $15 \mathrm{~min}$. The lysate was subsequently aliquoted and stored at $-20{ }^{\circ} \mathrm{C}$ until the day of assay. One aliquot was used to determine protein concentration by the Lowry method (Lowry et al., 1951). 


\section{Binding assay}

$\mathrm{Tyr}^{11}$-SRIF was radioiodinated by the chloramine-T method according to Greenwood et al. (1963). The tracer was purified in a Sephadex G-25 fine column $(1 \times 100 \mathrm{~cm})$ equilibrated with $0.1 \mathrm{M}$ acetic acid containing BSA $0.1 \%(\mathrm{w} / \mathrm{v})$. The specific activity of the purified labeled peptide was about $600 \mathrm{Ci} / \mathrm{mmol}$. Membranes from the rat temporal cortex were prepared as previously described by Reubi et al. (1981). The protein concentration was assayed by the Lowry method, with BSA as a standard. Specific SRIF binding was measured according to the modified method of Czernik and Petrack (1983). Briefly, the membranes $(0.15 \mathrm{mg}$ protein $/ \mathrm{mL})$ were incubated in $250 \mu \mathrm{L}$ of a medium containing $50 \mathrm{mM}$ Tris- $\mathrm{HCl}$ buffer ( $\mathrm{pH} 7.5$ ), $5 \mathrm{mM} \mathrm{MgCl}, 0.2 \%$ (w/v) BSA and $0.1 \mathrm{mg} / \mathrm{mL}$ bacitracin with $250 \mathrm{pM}$ of ${ }^{125}$ I-Tyr ${ }^{11}$-SRIF, either in the absence or presence of 0.01-10 nM unlabeled SRIF. After one 60-min incubation at $30^{\circ} \mathrm{C}$, bound and free ligand were separated by centrifugation at $11,000 \times g$ for $2 \mathrm{~min}$ and the radioactivity in the resultant pellet was measured. Nonspecific binding was obtained from the amount of radioactivity bound in the presence of $10^{-7} \mathrm{M}$ SRIF and represented about $20 \%$ of the binding observed in the absence of unlabeled peptide. This nonspecific component was subtracted from the total bound radioactivity in order to obtain the corresponding specific binding.

\section{AC assay}

AC activity was measured as previously reported (Houslay et al., 1976), with minor modifications. Briefly, membranes from the temporal cortex $(0.06 \mathrm{mg} / \mathrm{mL})$ were incubated with $1.5 \mathrm{mM}$ ATP, $5 \mathrm{mM} \mathrm{MgSO}{ }_{4}, 10 \mu \mathrm{M}$ GTP, an ATP-regenerating system (7.5 $\mathrm{mg} / \mathrm{mL}$ creatine phosphate and $1 \mathrm{mg} / \mathrm{mL}$ creatine kinase), $1 \mathrm{mM}$ IBMX, $0.1 \mathrm{mM}$ PMSF, $1 \mathrm{mg} / \mathrm{mL}$ bacitracin, $1 \mathrm{mM}$ EDTA, and test substances $\left(10^{-4} \mathrm{M}\right.$ SRIF or $\left.10^{-5} \mathrm{M} \mathrm{FK}\right)$ in $0.1 \mathrm{~mL}$ of $0.025 \mathrm{M}$ triethanolamine $/ \mathrm{HCl}$ buffer, $\mathrm{pH}$ 7.4. After one 15-min incubation at $30{ }^{\circ} \mathrm{C}$, the reaction was stopped by heating the mixture for $3 \mathrm{~min}$ at $90{ }^{\circ} \mathrm{C}$. After cooling, $0.2 \mathrm{~mL}$ of an alumina slurry $(0.75 \mathrm{~g} / \mathrm{mL}$ in triethanolamine/ $\mathrm{HCl}$ buffer, $\mathrm{pH}$ 7.4) was added and the suspension was centrifuged. The supernatant was taken for assay of cAMP by the method of Gilman (1970).

\section{RT and the polymerase chain reaction}

Total RNA was isolated from the temporal cortex in guanidinium isothiocyanate, using a commercial kit (Tri Reagent). The total RNA samples were digested with DNase I, purified with phenolchloroform-isoamyl alcohol $(1: 1: 0.02)$ and stored at $-80^{\circ} \mathrm{C}$ until analysis. The RNA concentration and purity in the final preparation were spectrophotometrically quantified by measuring the absorbance at 260 and $280 \mathrm{~nm}$ (Ultrospec Plus UV/Vis Spectrophotometer, Pharmacia Biotech, Uppsala, Sweden). The RNA integrity was checked on a denaturing $1.5 \%$ agarose gel stained with ethidium bromide. Total RNA $(1 \mu \mathrm{g})$ was primed with Oligo(dT) $)_{12-18}$ and incubated with MMLV-RT to synthesize cDNA. An RT reaction in the absence of MMLV-RT was performed as a control for genomic DNA contamination. The sst2 primers used for PCR amplification are shown in Table 1. The following conditions were used: denaturation at $94{ }^{\circ} \mathrm{C}$ for $1 \mathrm{~min}$, annealing at $55{ }^{\circ} \mathrm{C}$ for $30 \mathrm{~s}$, and extension at $72{ }^{\circ} \mathrm{C}$ for $90 \mathrm{~s}$. $\beta$-Actin primers were added as an internal standard (Table 1). Sst2 was coamplified with $\beta$-actin for 30 cycles, followed by a final extension at $72{ }^{\circ} \mathrm{C}$ for $10 \mathrm{~min}$. Following PCR, the samples were run on an agarose gel (with a density gradient of $2 \%-1.5 \%-1 \%$ ) and the bands were visualized after staining with ethidium bromide.

\section{Immunodetection of the $\alpha \mathrm{i}$ subunits of $\mathrm{G}$ proteins, GRK2, phospho-CREB, total-CREB and sst1-sst4}

The membranes and cell lysates were solubilized in SDS-sample buffer and the proteins $(100 \mu \mathrm{g})$ were then run on a $12 \%$ SDS-
Table 1. Nucleotide sequence of the PCR primers and size of the amplified products

\begin{tabular}{lll}
\hline Gene & Sequence & Size (bp) \\
\hline sst2 & & \\
Sense & 5'AGC AAC GCG GTC CTC ACG TT-3' & 973 \\
Antisense & 5'GGA GGT CTC CAT TGA GGA GG-3' & \\
$\beta$-Actin & & \\
Sense & 5'TGA CCC AGA TCA TGT TTG AGA-3' & 484 \\
Antisense & 5'ACT CCA TGC CCA GGA AGG A-3' & \\
\hline
\end{tabular}

polyacrylamide gel. After separation, the proteins were transferred onto nitrocellulose membranes in a buffer containing $25 \mathrm{mM}$ Tris$\mathrm{HCl}, \mathrm{pH} 8.3,192 \mathrm{mM}$ glycine, $20 \%$ methanol and $0.05 \%$ SDS. The nitrocellulose membranes were then blocked with TTBS (50 mM Tris- $\mathrm{HCl}, \mathrm{pH} 7.5,150 \mathrm{mM} \mathrm{NaCl}$, and $0.05 \%$ Tween-20) containing $5 \%(\mathrm{w} / \mathrm{v})$ non-fat dry milk for $1.5 \mathrm{~h}$ at $4{ }^{\circ} \mathrm{C}$. The nitrocellulose membranes were subsequently incubated with the corresponding antibodies: mouse anti-Gi $\alpha 1$, anti-Gi $\alpha 2$, or anti-GRK2 monoclonal antibodies (1:1000 dilution), rabbit anti-Gi $\alpha 3$ polyclonal antibody (1:1000 dilution), rabbit anti-phospho-CREB or anti-CREB monoclonal antibody (1:1000 dilution) or goat anti-sst1, anti-sst2, antisst3 or anti-sst4 polyclonal antibody (1:1000 dilution) in TTBS overnight at $4{ }^{\circ} \mathrm{C}$. After incubation, three 5-min washes in TTBS containing $5 \%(\mathrm{w} / \mathrm{v})$ non-fat dry milk were carried out. A goat, mouse or rabbit IgG-peroxidase conjugate (1:2000 dilution) in TTBS was then added to the membranes and incubated for $1 \mathrm{~h}$ at $4{ }^{\circ} \mathrm{C}$. After washing, the bound immunoreactive proteins were detected by a chemiluminescent (ECL) Western blotting detection system. Quantification of the bands was carried out by densitometric analysis using the Scion Image computer program (Scion Inc.).

\section{Data analysis}

The computer program LIGAND (Munson and Rodbard, 1980) was used to analyze the binding data. The use of this program enables models of receptors which best fit a given set of binding data to be selected. The same program was also used to present data in the form of Scatchard plots and to compute values for receptor affinity (Kd) and density (Bmax) that best fit the sets of binding data for each rat. Statistical comparisons of all data were carried out by one-way analysis of variance (ANOVA) and the Student-Newman-Keuls test. Means among groups were considered significantly different when the $P$ values were less than 0.05 . Each experiment was performed in duplicate.

\section{RESULTS}

Membranes from the temporal cortex of the different experimental groups bound [ $\left.{ }^{125} \mid-\mathrm{Tyr}^{11}\right]$-SRIF in a time-dependent manner, with a maximal specific binding at $30^{\circ} \mathrm{C}$, $60 \mathrm{~min}$, remaining stable thereafter until at least $120 \mathrm{~min}$ (data not shown). A 60-min incubation period was thus chosen to study the stoichiometry of the binding reaction. SRIF degradation by the membranes was also assessed in order to rule out the possibility of different SRIF degrading activities that could affect the interpretation of the results. All membrane preparations showed similar levels of SRIF degradation, with values varying by no more than $11.5 \%$. SRIF competitively inhibited the specific binding of [ ${ }^{125} \mathrm{I}-$ $\mathrm{Tyr}^{11}$ ]-SRIF to its membrane receptors in the rat temporal cortex of all the experimental animals (Fig. 1, left panel). 


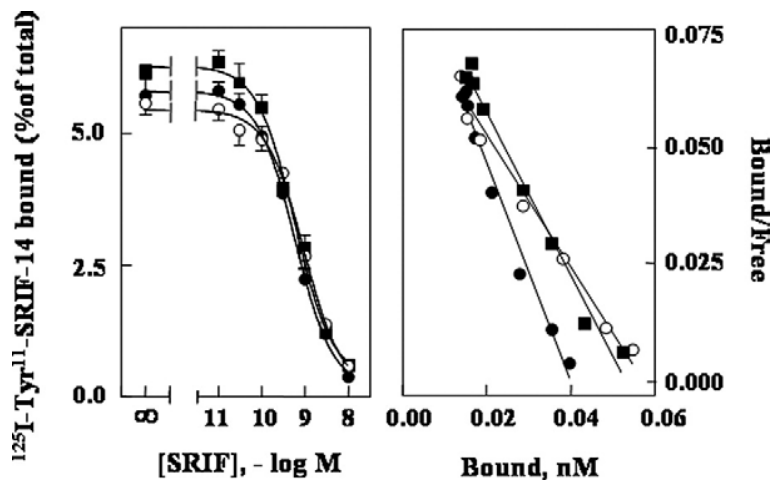

Fig. 1. Effect of chronic i.c.v. infusion of $A \beta(25-35)$ for 14 days on SRIF binding to its receptors in membranes from the rat temporal cortex. Left panel: Competitive inhibition of specific ${ }^{125} \mid{ }_{-T y}{ }^{11}$-SRIF binding by unlabeled SRIF to membranes from the rat temporal cortex. Membranes $(0.15 \mathrm{mg}$ protein $/ \mathrm{mL})$ were incubated for $60 \mathrm{~min}$ at $30^{\circ} \mathrm{C}$

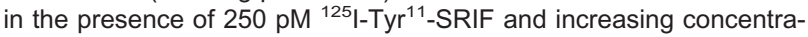
tions of native peptide. Points correspond to values for the control rats $(\bigcirc ; n=5)$, rats treated with $\mathrm{A} \beta(25-35)(300 \mathrm{pmol} /$ day for 14 days) (๑; $n=5)$ and rats treated with minocycline $(45 \mathrm{mg} / \mathrm{kg}$, i.p. twice on the first day and $22.5 \mathrm{mg} / \mathrm{kg}$ on days 13 and 14$)$ plus $A \beta(25-35)$ (300 pmol/day for 14 days) $(\boldsymbol{\square} ; n=5)$. Each point represents the mean \pm S.E.M. of five rats. Each experiment was performed in duplicate. Right panel: Scatchard analysis of the binding data. For details, see Experimental Procedures.

The specific binding of the tracer in the $A \beta(25-35)$-treated group, however, was significantly lower than that in the control group, in the absence or presence of SRIF. The corresponding equilibrium parameters for the SRIF receptors, shown in Table 2, reveal that $A \beta(25-35)$ administration decreased the density and the dissociation constant of the SRIF receptors in the temporal cortex. Minocycline treatment prevented the $A \beta(25-35)$-induced decrease in the SRIF receptor density, but exerted no effect on either parameter when administered alone to control rats (Table 2).

To test which SRIF receptor subtypes were affected by these treatments, Western blot analyses of sst1-4 were per-

Table 2. Effect of chronic i.c.v. infusion of $A \beta(25-35)$ and minocycline administration on the SRIF receptor binding parameters

\begin{tabular}{llll}
\hline \multirow{2}{*}{ Groups } & \multicolumn{3}{l}{ SRIF receptors } \\
\cline { 2 - 4 } & Bmax & Kd & $n$ \\
\hline Control & $441 \pm 20$ & $0.76 \pm 0.12$ & 5 \\
Minocycline & $423 \pm 64$ & $0.85 \pm 0.08$ & 5 \\
A $\beta(25-35)$ & $239 \pm 41^{*}$ & $0.34 \pm 0.10^{*}$ & 5 \\
A $\beta(25-35)$ plus minocycline & $464 \pm 56$ & $0.44 \pm 0.09$ & 5 \\
\hline
\end{tabular}

Equilibrium parameters for SRIF binding to membranes from the temporal cortex of control rats $(n=5)$, rats treated with $\mathrm{A} \beta(25-35)(300$ $\mathrm{pmol} /$ day for 14 days) $(n=5)$, rats treated with minocycline $(45 \mathrm{mg} / \mathrm{kg}$, i.p. twice on the first day and $22.5 \mathrm{mg} / \mathrm{kg}$ on days 13 and 14) and rats treated with minocycline $(45 \mathrm{mg} / \mathrm{kg}$, i.p. twice on the first day and $22.5 \mathrm{mg} / \mathrm{kg}$ on days 13 and 14$)$ plus $\mathrm{A} \beta(25-35)$ (300 pmol/day for 14 days) $(n=5)$. Binding parameters were calculated from Scatchard plots by linear regression. Units for $\mathrm{Kd}$ are $\mathrm{nM}$ and units for Bmax are femtomoles of SRIF bound per mg of protein. The results represent the mean \pm S.E.M. of five rats. Each experiment was performed in duplicate.

${ }^{*} P<0.05$, statistical comparison versus control.

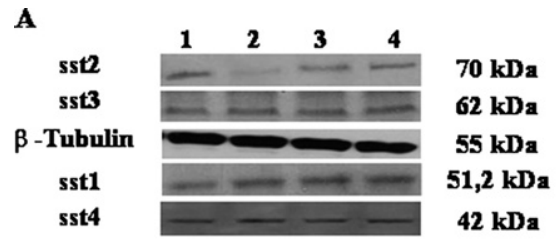

B

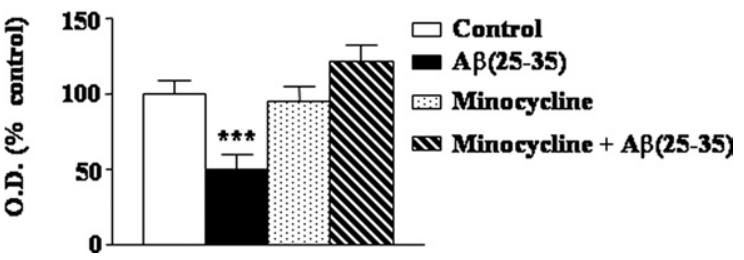

Fig. 2. (A) Autoradiographs derived from the immunoblots of the different sst subtypes (sst1-sst4) in membranes from the rat temporal cortex. Lane 1 corresponds to control rats $(n=5)$, lane 2 to rats treated with $\mathrm{A} \beta(25-35)$ ( $300 \mathrm{pmol} / \mathrm{day}$ for 14 days) $(n=5)$, lane 3 to rats treated with minocycline $(45 \mathrm{mg} / \mathrm{kg}$, i.p. twice on the first day and $22.5 \mathrm{mg} / \mathrm{kg}$ on days 13 and 14) and lane 4 to rats treated with minocycline ( $45 \mathrm{mg} / \mathrm{kg}$, i.p. twice on the first day and $22.5 \mathrm{mg} / \mathrm{kg}$ on days 13 and 14) plus $A \beta(25-35)$ ( $300 \mathrm{pmol} / \mathrm{day}$ for 14 days). The membrane proteins were resolved by SDS-PAGE as described in the Experimental Procedures section. Proteins were transferred to nitrocellulose membranes and immunodetection was carried out by using a goat anti-sst1, anti-sst2, anti-sst 3 or anti-sst 4 polyclonal antibody. Each experiment is representative of five others. An anti- $\beta$ tubulin antibody was used to check for equal loading. (B) Densitometric analysis of the autoradiographs derived from the immunoblots of the sst2 subtype. The integrated optical densities are presented as a percent of the control value. Statistical comparison versus control: ${ }^{* * *} P<0.001$.

formed in membranes from the rat temporal cortex. A significant decrease in sst2 protein levels was found in the $A \beta(25-$ 35)-treated group, no significant differences being observed in either sst1, sst3 or sst4 protein content (Fig. 2). Minocycline administration, however, abrogated the $A \beta(25-35)$-induced decrease in sst2 protein expression, exerting no effect on this parameter when administered alone to rats treated with vehicle (Fig. 2).

A functional cyclic AMP response element (CRE) has been identified within the second promoter of the rat sst2 gene (Kimura et al., 2001). Sst2 expression is known to be induced by cAMP (Kraus et al., 2000). Classically, elevation of intracellular cAMP levels leads to protein kinase $A$ (PKA) activation. The activated catalytic subunit of PKA enters the cell nucleus, where CREB is phosphorylated. Binding of phosphorylated cyclic AMP response element binding protein ( $p$-CREB) to CRE then leads to enhanced gene transcription (Mayr and Montminy, 2001). In view of this, we next sought to examine the levels of $p$-CREB and total CREB in order to gain further insight into the mechanism underlying the $A \beta(25-35)$-induced decrease in SRIF binding and sst2 expression and its restoration by minocycline. We proposed that these treatments might be altering the rate of gene transcription by modifying the levels of the activated form of CREB. Western blot analysis revealed that whereas $A \beta(25-35)$ administration induces a significant decrease in both $p$-CREB and total CREB content in the rat temporal cortex, this effect is completely abrogated by minocycline pretreatment (Fig. 3). Minocy- 
cline alone significantly enhanced p-CREB protein levels in this brain area (Fig. 3). Likewise, total CREB content was increased by minocycline, suggesting that the drug alters not only the degree of CREB phosphorylation but its synthesis as well.

To further investigate the protective effects of minocycline on sst2 protein expression, the mRNA levels of this receptor subtype were determined by RT-PCR. Chronic $A \beta(25-35)$ infusion led to a reduction in sst2 mRNA levels in the rat temporal cortex. Minocycline treatment alone to vehicle-injected rats led to a rise in sst2 mRNA levels and when administered to $A \beta(25-35)$-infused rats, restored mRNA levels to control values (Fig. 4).

On the other hand, different members of the GPCR family are known to desensitize and internalize upon phosphorylation by GRKs. Hence, there lies the possibility that the $A \beta(25-35)$-induced decrease in sst2 protein content might be, at least partly, attributable to an increased rate of internalization of the receptor by GRK-mediated phosphorylation. To explore this alternative hypothesis, we analyzed GRK2 protein expression, the isoform most abundantly expressed in the cerebral cortex, by Western blotting using a subtype-specific monoclonal antibody. An enhanced expression of GRK2 was detected in animals infused chronically with $A \beta(25-35)$, as compared with GRK2 protein levels in control rats (Fig. 5). Minocycline pre-treatment prevented the rise in GRK2 levels, whereas it exerted no effect on this parameter when administered to rats treated with vehicle (Fig. 5).

$\mathbf{A}$

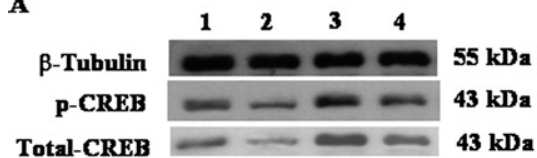

B

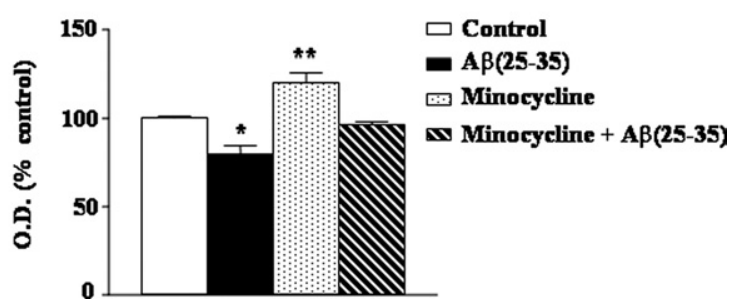

Fig. 3. (A) Autoradiographs derived from the immunoblots of $p-C R E B$ and total CREB in cells extracts from the rat temporal cortex. Lane 1 corresponds to control rats $(n=5)$, lane 2 to rats treated with $\mathrm{A} \beta(25-35)$ ( $300 \mathrm{pmol} / \mathrm{day})$ for 14 days $(n=5)$, lane 3 to rats treated with minocycline $(45 \mathrm{mg} / \mathrm{kg}$, i.p. twice on the first day and $22.5 \mathrm{mg} / \mathrm{kg}$ on days 13 and 14$)$ and lane 4 to rats treated with minocycline $(45 \mathrm{mg} / \mathrm{kg}$, i.p. twice on the first day and $22.5 \mathrm{mg} / \mathrm{kg}$ on days 13 and 14$)$ plus $\mathrm{A} \beta(25-35)$ (300 pmol/day for 14 days). The membrane proteins were resolved by SDS-PAGE as described in the Experimental Procedures section. Proteins were transferred to nitrocellulose membranes and immunodetection was carried out by using a rabbit anti-CREB and anti-pCREB monoclonal antibody. Each experiment is representative of five others. An anti- $\beta$ tubulin antibody was used to check for equal loading. (B) Densitometric analysis of p-CREB content in the temporal cortex of control rats and rats treated with $A \beta(25-35)$, minocycline or minocycline plus $A \beta(25-35)$. The results were normalized with total CREB content. The data represent the mean \pm S.E.M. of five rats. Statistical comparison versus control: ${ }^{*} P<0.05$; ${ }^{* *} P<0.01$.

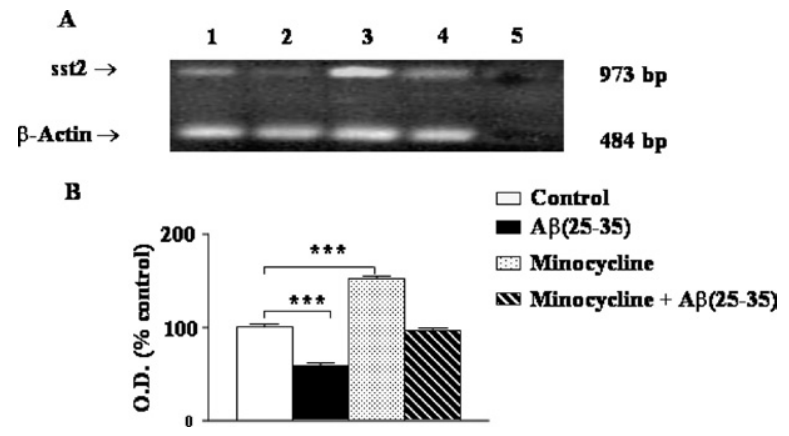

Fig. 4. Detection of sst2 mRNA in the rat temporal cortex by RT-PCR. (A) Total RNA isolated from control rats (lane $1, n=5$ ), rats treated with A $\beta(25-35$ ) (lane $2, n=5$ ), rats treated with minocycline (lane $3, n=5$ ) and rats treated with minocycline and $A \beta(25-35)$ (lane $4, n=5$ ) was subjected to RT-PCR with primers specific for sst2 and $\beta$-actin. To control for contaminating cDNA, samples were processed in an identical manner except reverse transcriptase was omitted from the mix (lane 5). The PCR products were separated by agarose gel (1\%) electrophoresis and visualized by ethidium bromide staining. (B) Densitometric analysis of the observed bands in the temporal cortex of control rats and rats treated with $A \beta(25-35)$, minocycline or minocycline plus $A \beta(25-35)$. The results were normalized with $\beta$-actin. The data represent the mean \pm S.E.M. of five rats. Statistical comparison versus control: ${ }^{* * *} P<0.001$.

All SRIF receptor subtypes couple negatively to the effector AC, leading to a reduction in CAMP production. Thus, our next goal was to assess the functionality of the SRIF receptors. To this end, we measured the effects of $\mathrm{A} \beta(25-35)$, minocycline and minocycline plus $A \beta(25-35)$ administration on basal and FK-stimulated AC activity, as
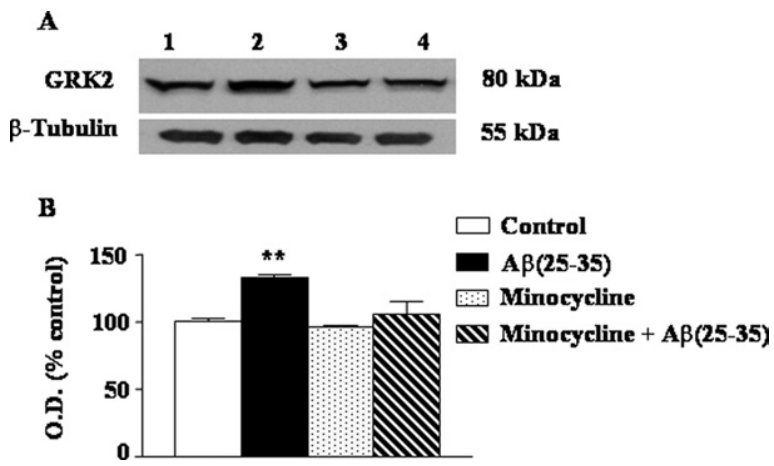

Fig. 5. (A) Autoradiographs derived from the immunoblots of the GPCR kinase isoform GRK2 in membranes from the rat temporal cortex. Lane 1 corresponds to control rats $(n=5)$, lane 2 to rats treated with $\mathrm{A} \beta(25-35)$ ( $300 \mathrm{pmol} / \mathrm{day}$ for 14 days) $(n=5)$, lane 3 to rats treated with minocycline $(45 \mathrm{mg} / \mathrm{kg}$, i.p. twice on the first day and $22.5 \mathrm{mg} / \mathrm{kg}$ on days 13 and 14) and lane 4 to rats treated with minocycline ( $45 \mathrm{mg} / \mathrm{kg}$, i.p. twice on the first day and $22.5 \mathrm{mg} / \mathrm{kg}$ on days 13 and 14) plus $A \beta(25-35)$ ( $300 \mathrm{pmol} / \mathrm{day}$ for 14 days). The membrane proteins were resolved by SDS-PAGE as described in the Experimental Procedures section. Proteins were transferred to nitrocellulose membranes and the immunodetection was carried out by using a mouse anti-GRK2 monoclonal antibody. Each experiment is representative of five others. An anti- $\beta$ tubulin antibody was used to check for equal loading. (B) Densitometric analysis of the autoradiographs derived from the immunoblots of GRK2 in the temporal cortex from the different experimental groups. The integrated optical densities for the different experimental groups are presented as a percent of the control value. Statistical comparison versus control: ${ }^{* *} P<0.01$. 
Table 3. AC activity (pmol cAMP/min/mg protein) in the absence (basal activity) or presence of FK $\left(10^{-5} \mathrm{M}\right)$ and SRIF $\left(10^{-4} \mathrm{M}\right)$-mediated inhibition of $\mathrm{AC}$ activity in membranes from the temporal cortex of control rats $(n=5)$, rats treated with $\mathrm{A} \beta(25-35)$, rats treated with minocycline $(n=5)$ and rats treated with minocycline plus $\mathrm{A} \beta(25-35)(n=5)$

\begin{tabular}{lcccc}
\hline AC activity & Control & $\mathrm{A} \beta(25-35)$ & Minocycline & Minocycline $+\mathrm{A} \beta(25-35)$ \\
\hline Basal activity & $331 \pm 16$ & $294 \pm 10$ & $325 \pm 26$ & $322 \pm 11$ \\
$\%$ SRIF inhibition of basal activity & $36.0 \pm 1.5$ & $18.7 \pm 6.2^{*}$ & $40.3 \pm 9.3$ & $34.4 \pm 9.3$ \\
$+10^{-5}$ M FK & $1147 \pm 43$ & $1161 \pm 51$ & $1146 \pm 15$ & $1093 \pm 46$ \\
$\%$ SRIF inhibition of FK-stimulated activity & $37.4 \pm 1.1$ & $22 \pm 2.7^{\star *}$ & $41.6 \pm 13.7$ & $32.0 \pm 1.1$ \\
Fold FK stimulation & $3.3 \pm 0.2$ & $3.7 \pm 0.2$ & $3.6 \pm 0.4$ & $3.4 \pm 0.2$ \\
\hline
\end{tabular}

Data are expressed as the mean \pm S.E.M. of five rats. Each experiment was performed in duplicate. Statistical analysis was performed by ANOVA. ${ }^{*} P<0.05$, statistical comparison versus control.

${ }^{* *} P<0.01$, statistical comparison versus control.

well as the capacity of SRIF to inhibit these activities. As shown in Table 3, no significant differences in either basal or FK-stimulated AC activity were found in temporal cortical membranes from the different experimental groups under analysis. Likewise, basal or FK-stimulated AC activity was inhibited by SRIF in all the experimental animals. In the $A \beta(25-35)$-treated group, however, the capacity of SRIF to inhibit basal or FK-stimulated AC activity in these membranes was attenuated (Table 3), an effect which was abolished by minocycline treatment (Table 3 ).

It is well established that all three $\mathrm{G}$ proteins belonging to the $\mathrm{Gi}$ family, namely $\mathrm{Gi} \alpha 1, \mathrm{Gi} \alpha 2$, and $\mathrm{Gi} \alpha 3$, couple ssts to $A C$. Hence, this raises the question of whether the attenuated ability of SRIF to inhibit AC activity in the $A \beta(25-35)$-treated rats might be a consequence of changes at the Gi level. To address this issue, Western blot analyses of the $\alpha \mathrm{i} 1, \alpha \mathrm{i} 2$ and $\alpha \mathrm{i} 3$ subunits of Gi proteins were performed in temporal cortical membranes from control, $A \beta(25-35)-$, minocycline-, and minocycline plus $\mathrm{A} \beta(25-35)-$ treated rats. The results obtained demonstrate that neither $A \beta(25-35)$ nor minocycline alters the protein expression of any of the three $\alpha$ i subunits studied (Fig. 6).

\section{DISCUSSION}

The main finding here is that minocycline exerts a protective role against $A \beta(25-35)$-induced impairment of the SRIF signaling pathway in the rat temporal cortex.

Chronic i.c.v infusion of $A \beta(25-35)$, located at the Cterminus of $A \beta(1-42)$, was used to partially reproduce $A D$ in rats. The experimental conditions were selected according to previous studies demonstrating that they mimic some of the pathological processes in $A D$ brain, including the cognitive deficits (Nitta et al., 1994). This fragment is proposed to be the functional domain of $A \beta$ responsible for its neurotoxic properties (Pike et al., 1993). In the past, the presence of $A \beta(25-35)$ in vivo was controversial. Kubo et al. (2002) have provided evidence that insoluble $A \beta(1-40)$, present in the senile plaques characteristic of $A D$, can be racemized at $\mathrm{Ser}^{26}$, possibly during the aging process, to yield soluble $\left[\mathrm{D}-\mathrm{Ser}^{26}\right] \mathrm{A} \beta(1-40)$; this fragment is released from the plaques and degraded by proteases, generating the toxic fragments [D-Ser $\left.{ }^{26}\right] A \beta(25-35)$ and $\left[D-S^{26}\right] A \beta(25-40)$, both protease-resistant. Histochemical analysis with specific antibodies to [D-Ser $\left.{ }^{26}\right] \mathrm{A} \beta(25-35)$ and [D-Ser $\left.{ }^{26}\right] \mathrm{A} \beta(25-40)$ clearly revealed the presence of both fragments in the $A D$ brain but not in age-matched control brains (Kubo et al., 2002).

After continuous $A \beta(25-35)$ infusion, a decrease in sst density was detected in the rat temporal cortex, consistent with data previously published by our group (Aguado-Llera et al., 2005) and found in the postmortem cerebral cortex of AD patients (Krantic et al., 1992). The $A \beta(25-35)$-induced reduction in the rat temporal cortex is partly due to a selective decrease in sst2 expression. Although the lower sst2 protein levels might be attributable to post-
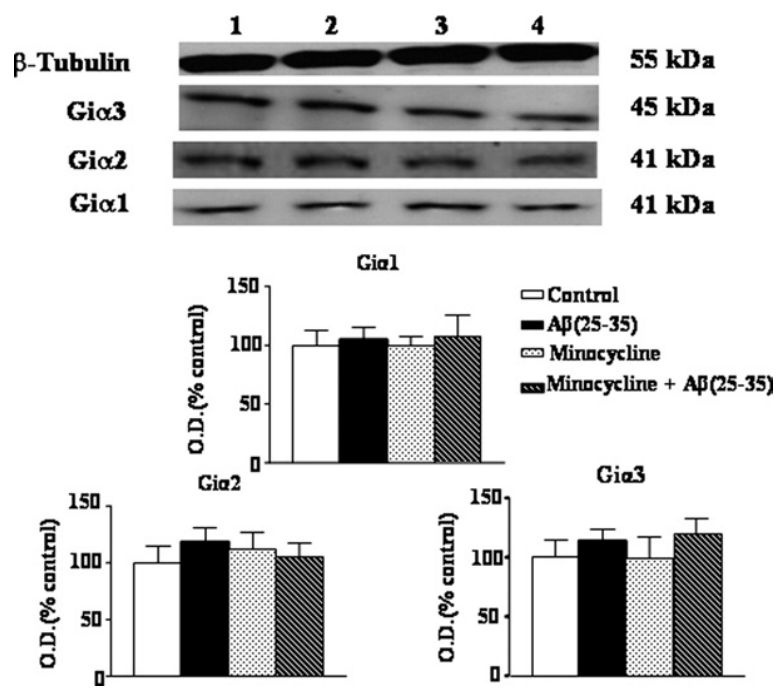

Fig. 6. Autoradiographs derived from the immunoblots of the $\alpha \mathrm{i} 1, \alpha \mathrm{i} 2$ and $\alpha \mathrm{i} 3$ subunits of $\mathrm{Gi}$ proteins in membranes from the rat temporal cortex. Upper panel: Lane 1 corresponds to control rats $(n=5)$, lane 2 to rats treated with $A \beta(25-35)$ (300 pmol/day for 14 days) $(n=5)$, lane 3 to rats treated with minocycline $(45 \mathrm{mg} / \mathrm{kg}$, i.p. twice on the first day and $22.5 \mathrm{mg} / \mathrm{kg}$ on days 13 and 14) and lane 4 to rats treated with minocycline $(45 \mathrm{mg} / \mathrm{kg}$, i.p. twice on the first day and $22.5 \mathrm{mg} / \mathrm{kg}$ on days 13 and 14) plus $A \beta(25-35)$ (300 pmol/day for 14 days). The membrane proteins were resolved by SDS-PAGE as described in the Experimental Procedures section. Proteins were transferred to nitrocellulose membranes and immunodetection was carried out by using a mouse anti-Gi $\alpha 1$ or anti-Gi $\alpha 2$ monoclonal antibody, or a rabbit anti$\mathrm{Gi} \alpha 3$ polyclonal antibody. Each experiment is representative of five others. An anti- $\beta$ tubulin antibody was used to check for equal loading. Data represent the mean \pm S.E.M. of five rats. Lower panel: Densitometric analysis of the autoradiographs derived from the immunoblots of $\mathrm{Gi}$ proteins in the temporal cortex from the different experimental groups. The integrated optical densities for the different experimental groups are presented as a percent of the control value. 
translational modifications and/or alterations in protein stability, the fact that sst2 mRNA levels were also reduced after $A \beta(25-35)$ administration points toward a decreased rate of gene transcription. Sstll is the main subtype expressed in the cerebral cortex and is a prototype of a receptor whose gene contains a CRE regulated by the transcription factor CREB (Kraus et al., 2000). Phosphorylation of CREB on Ser-133 is required for the recruitment of the co-activator CBP and thus, for initiation of CREBdependent transcription (Mayr and Montminy, 2001). Here we show that $A \beta(25-35)$ treatment induces a reduction in $\mathrm{p}$-CREB immunoreactivity in the temporal cortex, which could account for the lower sst2 mRNA levels. This finding is concordant with in vitro studies in which $A \beta(1-40)$ was shown to suppress CREB phosphorylation in cultured cortical neurons (Tong et al., 2001). Notwithstanding, other transcription factors might also be involved. Kimura et al. (2001) reported that the rat sst2 promoter contains consensus motifs for transcription factors such as T3R, ER or NF-kappaB and that rat sst2 mRNA levels are up-regulated by chronic treatment with estrogen, suggesting that the CRE site partly mediates the promoter activity activated by estrogen.

Minocycline is a lipid-soluble tetracycline that easily crosses the blood-brain barrier (Aronson, 1980) and has been documented to exert an inhibitory effect on $A \beta$ fibril formation and microglial activation (Seabrook et al., 2006). The doses used in our experiments were selected according to a previous study carried out by Yrjänheikki et al. (1999) who showed that they exert neuroprotective effects in global brain ischemia. The changes in ${ }^{125} \mathrm{I}-\mathrm{Tyr}^{11}$-SRIF binding and sst 2 mRNA and protein content detected after $A \beta(25-35)$ infusion were abrogated by minocycline treatment. Minocycline administration to $A \beta(25-35)$-infused rats also normalized $\mathrm{p}-\mathrm{CREB}$ and total CREB levels. CREB phosphorylation is regulated by a variety of cellular signaling pathways involved in growth, development and differentiation. MAPK and ERK, for example, have been shown to activate CREB, reducing apoptosis in human neuroblastoma cells (Park and Cho, 2006). In addition, the Akt signaling pathway modulates cell integrity and cell survival via activation of several substrates, including CREB (Chong et al., 2005). Pi et al. (2004) have demonstrated that minocycline enhances Akt phosphorylation, triggered by phosphatidylinositol-3-kinase signaling, in cerebellar neurons. In view of these findings, it is feasible that minocycline might increase CREB phosphorylation in the temporal cortex via the Akt pathway, thereby leading to enhanced sst2 transcription, thus counteracting the effect of $\mathrm{A} \beta(25-35)$ on sst2 expression.

Whereas multiple mechanisms contribute to the regulation of GPCRs, GRKs and arrestins play a key role. GRKs comprise a family of serine/threonine kinases that are uniquely able to associate with the agonist-occupied form of the receptor (Gainetdinov et al., 2004). Signaling is terminated upon receptor phosphorylation and subsequent binding of arrestins, uncoupling the receptor from the Gprotein. GRKs can be divided into three subgroups based on sequence and functional criteria: GRK1 and 7, ex- pressed almost exclusively in retina, GRK2 and 3, and GRK4-5 and 6, which are ubiquitously expressed (Gainetdinov et al., 2004). GRK2-6 are all found in the brain, suggesting an important role in neuronal signal transduction (Gainetdinov et al., 2004). In our study, the decrease in sst2 protein levels in the temporal cortex of the $A \beta(25-$ 35)-infused rats was associated with a significant enhancement of GRK2 immunoreactivity. The number of cell surface receptors is a function of the combined processes of insertion of newly synthesized receptors into the plasma membrane and internalization of these receptors. Therefore, an altered rate of internalization could contribute to the decrease in sst2 protein content. Tulipano et al. (2004) demonstrated that in HEK293 cells transfected with both GRK2 and sst2A, sst2A internalization was dependent on GRK2-mediated phosphorylation of serine and threonine residues present in the C-terminus of the receptor. Agonist-induced phosphorylation of sst3, however, was GRK2-independent whereas neither sst1 nor sst4 exhibited phosphorylation. Furthermore, overexpression of GRK2 markedly increased sst2A phosphorylation, facilitating the recruitment of $\beta$-arrestin-2 to the plasma membrane. Several studies support the hypothesis that alterations in GRK protein expression represent another means of regulating GRK activity (Rockman et al., 1996). Hence, in our experimental model of $A D$, increased GRK2 protein levels could lead to increased sst2-GRK2 interaction and thereby, to an increased phosphorylation and internalization of the receptor, contributing to the reduction in sst2 expression and ${ }^{125} \mathrm{I}-\mathrm{Tyr}^{11}$-SRIF binding. The fact that sst1, sst3 and sst4 protein levels were unaltered after $\mathrm{A} \beta$ infusion is consistent with this hypothesis, since none of these receptors seem to be regulated by GRK2.

Minocycline administration to $A \beta(25-35)$-infused rats restored GRK2 levels to baseline values, concomitant with the normalization of sst2 expression and SRIF binding. GRK mRNA levels are altered in a number of pathologies associated with GPCR dysfunction (Gainetdinov et al., 2004) yet very little is known about the mechanisms governing GRK transcription. Protein kinase $C$ (PKC) has been demonstrated to enhance GRK2 promoter activity in cardiovascular cells (Ramos-Ruiz et al., 2000). A study of Nikodemova et al. (2006) suggests that minocycline inhibits PKC in microglial cells. Therefore it is feasible that minocycline could abrogate the rise in GRK2 expression induced by $A \beta(25-35)$ via PKC inhibition, thus restoring sst2 mRNA and protein levels to control values.

Finally, $A \beta(25-35)$ administration led to a decrease in SRIF-mediated inhibition of AC activity, with no changes in either basal or FK-stimulated AC activity. This suggests that the decreased sensitivity of AC to SRIF was not due to an alteration in the catalytic subunit of the enzyme. In addition, $\mathrm{Gi} \alpha 1, \mathrm{Gi} \alpha 2$ and $\mathrm{Gi} \alpha 3$ protein levels were unaltered by $A \beta(25-35)$. Taken together, these findings suggest that the lower SRIF-mediated inhibition of AC activity is most probably due to the decrease in sst density. O'Neill et al. (1994) have shown a preservation of Gi-proteininhibited $A C$ activity in the frontoparietal cortex of $A D$ patients. In our study, minocycline administration to rats 
treated with either $A \beta(25-35)$ or vehicle did not alter basal or FK-stimulated AC activity. These results extend previous studies in vitro in which minocycline exerted no effect on cAMP formation in rat cerebral cortical slices (Mork and Geisler, 1993). In the $A \beta(25-35)$-treated group, however, minocycline restored the ability of SRIF to inhibit AC, most probably due to the normalization of sst2.

Given the potent amnesic properties reported for $A \beta(25-35)$ (Nitta et al., 1994) and the role of SRIF in cognitive processes (Dournaud et al., 1996), the $A \beta(25-$ $35)$-induced reduction in sst density and sst2 expression might be involved in the impairment of cognitive function reported by several laboratories after $A \beta$ administration. The fact that minocycline improves cognition in APP-transgenic mice suggests that this improvement might partly be accounted for by the protective effects of the drug on the SRIF signaling pathway. Our findings also suggest a possible link between sst2 and GRK2 in patients with AD. Future studies may shed new light on the potentially beneficial effects of minocycline in AD.

Acknowledgments-We wish to thank the staff of the Animal Centre of the Universidad de Alcalá for their support with the animal care and handling. This work was supported by a grant (SAF 2006-09454) from the Dirección General de Investigación del Ministerio de Ciencia y Tecnología of Spain and CIBER Fisiopatología de la Obesidad y Nutrición (CIBEROBN).

\section{REFERENCES}

Aguado-Llera D, Arilla-Ferreiro E, Campos-Barros A, Puebla-Jiménez L, Barrios V (2005) Protective effects of insulin-like growth factor-I on the somatostatinergic system in the temporal cortex of $\beta$-amyloid-treated rats. J Neurochem 92:607-615.

Aronson AL (1980) Pharmacotherapeutics of the newer tetracyclines. J Am Vet Med Assoc 176:1061-1068.

Bantubungi K, Jacquard C, Greco A, Pintor A, Chtarto A, Tai K, Galas MC, Tenenbaum L, Déglon N, Popoli P, Minghetti L, Brouillet E, Brotchi J, Levivier M, Schiffmann SN, Blum D (2005) Minocycline in phenotypic models of Huntington's disease. Neurobiol Dis 18:206-217

Beal MF, Mazurek MF, Svendsen CN, Bird ED, Martin JB (1986) Widespread reduction of somatostatin-like immunoreactivity in the cerebral cortex in Alzheimer's disease. Ann Neurol 20:489-495.

Beal MF, Mazurek MF, Tran VT, Chatta G, Bird ED, Martin JB (1985) Reduced numbers of somatostatin receptors in the cerebral cortex in Alzheimer's disease. Science 229:289-291.

Bissette G, Cook L, Smith W, Dole KC, Crain B, Nemeroff CB (1998) Regional neuropeptide pathology in Alzheimer's disease: corticotropinreleasing factor and somatostatin. J Alzheimers Dis 1:91-105.

Braak H, Braak E (1991) Neuropathological staging of Alzheimerrelated changes. Acta Neuropathol 82:239-259.

Burgos-Ramos E, Hervás-Aguilar A, Aguado-Llera D, Puebla-Jiménez L, Hernández-Pinto AM, Barrios V, Arilla-Ferreiro E (2008) Somatostatin and Alzheimer's disease. Mol Cell Endocrinol 286:104111.

Chong ZZ, Li F, Maiese K (2005) Activating Akt and the brain's resources to drive cellular survival and prevent inflammatory injury. Histol Histopathol 20:299-315.

Czernik AJ, Petrack V (1983) Somatostatin receptor binding in rat cerebral cortex. Characterization using a nonreducible somatostatin analog. J Biol Chem 285:5525-5530.

Davies P, Katzman R, Terry RD (1980) Reduced somatostatin-like immunoreactivity in cerebral cortex from cases of Alzheimer disease and Alzheimer senile dementia. Nature 288:279-280.
Dournaud P, Jazat-Pondessous F, Slama A, Lamour Y, Epelbaum J (1996) Correlations between water maze performance and cortical somatostatin mRNA and high-affinity binding sites during ageing in rats. Eur J Pharmacol 8:476-485.

Gainetdinov PR, Premont RT, Bohn LM, Lefkowitz RJ, Caron MG (2004) Desensitization of G-protein-coupled receptors and neuronal functions. Ann Res Neurosci 27:107-143.

Gilman AG (1970) A protein binding assay for adenosine 3':5'-cyclic monophosphate. Proc Natl Acad Sci U S A 67:305-312.

Greenwood FC, Hunter WM, Glover JS (1963) The preparation of ${ }^{131}$ I-labelled human growth hormone of high specific radioactivity. J Biochem 89:114-123.

Hervás-Aguilar A, Puebla-Jiménez L, Burgos-Ramos E, Aguado-Llera $D$, Arilla-Ferreiro $E$ (2005) Effects of single and continuous administration of amyloid $\beta$-peptide (25-35) on adenylyl cyclase activity and the somatostatinergic system in the rat frontal and parietal cortex. Neurosci 135:181-190.

Houslay MD, Metcalfe JC, Warren GB, Hesketh TR, Smith GA (1976) The glucagon receptor of rat liver plasma membrane can couple to adenylate cyclase without activating it. Biochim Biophys Acta 436:489-494.

Hoyer D, Bell GI, Berelowitz M, Epelbaum J, Feniuk W, Humprey PP, O'Carroll AM, Patel YC, Schonbrunn A, Taylor JE, Reisine T (1995) Classification and nomenclature of somatostatin receptors. Trends Pharmacol Sci 16:86-88.

Hsiao K, Chapman P, Nilsen S, Eckman C, Harigaya Y, Younkin S, Yang F, Cole G (1996) Correlative memory deficits, Abeta elevation, and amyloid plaques in transgenic mice. Science 274:99-102.

Hunter CL, Quintero EM, Gilstrap L, Bhat NR, Granholm AC (2004) Minocycline protects basal forebrain cholinergic neurons from $\mathrm{mu}$ p75-saporin immunotoxic lesioning. Eur J Neurosci 19:3305-3316.

Kimura N, Tomizawa S, Arai KN, Osamura RY, Kimura N (2001) Characterization of $5^{\prime}$-flanking region of rat somatostatin receptor sst2 gene: transcriptional regulatory elements and activation by Pitx1 and estrogen. Endocrinology 142:1427-1441.

Krantic S, Robitaille J, Quirion R (1992) Deficits in the somatostatin $\mathrm{SS}_{1}$ receptor subtype in frontal and temporal cortices in Alzheimer's disease. Brain Res 573:299-304.

Kraus J, Wöltje M, Schönwetter N, Hölt V (2000) Gene structure and regulation of the somatostatin receptor type 2. J Physiol 94: 199-204.

Kubo T, Nishimura S, Kumagae $Y$, Kaneko I (2002) In vivo conversion of racemized $\beta$-amyloid ([D-Ser $\left.\left.{ }^{26}\right] \mathrm{A} \beta 1-40\right)$ to truncated an toxic fragments ([D-Ser $\left.\left.{ }^{26}\right] A \beta 25-35 / 40\right)$ and fragment presence in the brains of Alzheimer's patients. J Neurosci Res 70:474-483.

Kumar U (2005) Expression of somatostatin receptor subtypes (SSTR1-5) in Alzheimer's disease brain: an immunohistochemical analysis. Neuroscience 134:525-538.

Lowry OH, Rosenbrough NJ, Farr AL, Randall RJ (1951) Protein measurement with the Folin phenol reagent. J Biol Chem 193: 265-275.

Mayr B, Montminy M (2001) Transcriptional regulation by the phosphorylation-dependent factor CREB. Nat Rev Mol Cell Biol 2: 599-609.

Mork A, Geisler A (1993) Effects of minocycline on accumulation of cyclic AMP in cerebral cortex of rat. A comparison with lithium. Neuropharmacology 32:793-798.

Munson PJ, Rodbard D (1980) Ligand: a versatile computerized approach for characterization of ligand-binding systems. Anal Biochem 107:220-239.

Nemeroff CB, Knight DL, Bissette G (1992) Somatostatin: a neuropeptide system pathologically altered in Alzheimer's disease and depression. Clin Neuropharmacol 15:311A-312A.

Nikodemova M, Duncan ID, Watters JJ (2006) Minocycline exerts inhibitory effects on multiple mitogen-activated protein kinases and IkappaBalpha degradation in a stimulus-specific manner in microglia. J Neurochem 96:314-323. 
Nitta A, Itoh A, Hasegawa T, Nabeshima T (1994) $\beta$-Amyloid proteininduced Alzheimer's disease animal model. Neurosci Lett 170: 63-66.

O'Neill C, Wiehager B, Fowler CJ, Ravid R, Winbland B, Cowburn RF (1994) Regionally selective alterations in G protein subunit levels in the Alzheimer's disease brain. Brain Res 636:193-201.

Park EM, Cho S (2006) Enhanced ERK dependent CREB activation reduces apoptosis in staurosporine-treated human neuroblastoma SK-N-BE(2)C cells. Neurosci Lett 402:190-194.

Patel YC (1999) Somatostatin and its receptor family. Front Neuroendocrinol 20:157-198.

Pi R, Li W, Lee NTK, Chan HHN, Pu Y, Chan LN, Sucher NJ, Chang DC, Han Y (2004) Minocycline prevents glutamate-induced apoptosis of cerebellar granule neurons by differential regulation of p38 and Akt pathways. J Neurochem 91:1219-1230.

Pike CJ, Brudick D, Walencevicz AJ, Glab CG, Cotman CW (1993) Neurodegeneration induced by $\beta$-amyloid peptides in vitro: the role of peptide assembly state. J Neurosci 13:1676-1687.

Ramos-Ruiz R, Penela P, Penn RB, Mayor F Jr (2000) Analysis of the human G-protein-coupled receptor kinase 2 (GRK2) gene promoter: regulation by signal transduction systems in aortic smooth muscle cells. Circulation 101:2083-2089.

Reubi JC, Perrin MH, Rivier JE, Vale W (1981) High affinity binding sites for a somatostatin-28 analog in rat brain. Life Sci 28: 2191-2198.

Rockman HA, Choi DJ, Rahman NU, Akhter SA, Lefkowitz RJ, Koch WJ (1996) Receptor-specific in vivo desensitization by the G protein-coupled receptor kinase- 5 in transgenic mice. Proc Natl Acad Sci U S A 93:9954-9959.
Ryu JK, Franciosi S, Sattayaprasert P, Kim SU, McLarnon JG (2004) Minocycline inhibits neuronal death and glial activation induced by $\beta$-amyloid peptide in rat hippocampus. Glia 48:85-90.

Seabrook TJ, Jiang L, Maier M, Lewere CA (2006) Minocycline affects microglial activation, $\mathrm{A} \beta$ deposition and behavior in APP-tg mice. Glia 53:776-782.

Selkoe DJ (2001) Alzheimer's disease: genes, proteins, and therapy. Physiol Rev 81:741-766.

Stroh T, Jackson AC, Sarret P, Dal Farra C, Vincent JP, Kreienkamp HJ, Mazella J, Beaudet A (2000) Intracellular dynamics of sst5 receptors in transfected COS-7 cells: maintenance of cell surface receptors during ligand-induced endocytosis. Endocrinology 141: 354-365.

Suo Z, Wu M, Citron BA, Wong GT, Festoff BW (2004) Abnormality of G-protein-coupled receptor kinases at prodromal and early stages of Alzheimer's disease: An association with early $\beta$-amyloid accumulation. J Neurosci 24:3444-3452.

Tong L, Thornton PL, Balazs R, Cotman CW (2001) Beta-amyloid-(142) impairs activity-dependent cAMP-responses element-binding protein signalling in neurons at concentrations in which cell survival is not compromised. J Biol Chem 276:17301-17306.

Tulipano G, Stumm R, Pfeiffer M, Kreinkamp HJ, Höllt V, Schluz S (2004) Differential $\beta$-arrestin trafficking and endosomal sorting of somatostatin receptor subtypes. J Biol Chem 279:21374-21382.

Yrjänheikki J, Thika T, Keinänen R, Goldsteins G, Chan PH, Koistinaho J (1999) A tetracycline derivative, minocycline, reduces inflammation and protects against focal cerebral ischemia with therapeutic window. Proc Natl Acad Sci U S A 93:13496-13500. 